\title{
VIEWPOINTS
}

\section{Halal Retailing: Closing the Last Mile in an End-To-End Halal Supply Chain}

\author{
Marco Tieman* \\ Barbara Ruiz-Bejarano**
}

\section{Background}

In 2010, the Department of Standards Malaysia introduced the world's first halal retailing standard: the "MS 2400-3:2010: management system requirements for retailing". This halal retailing standard intends to provide assurance of the halal integrity of products, goods and/or cargo at the retail stage. It specifies the framework a retailer should establish to meet regulatory halal requirements. In the implementation of the standard, the retailer should address the handling and managing of halal products and/or goods whenever there exist interfacing activities during receiving, loading and delivery. However, this management system is not prescriptive (read: silent) as to how purchasing needs be organised, what categories of halal retailers are possible, the layout of retail outlets, and whether there should be segregation at retail outlets and in logistics. It also leaves out considerations of consumer preferences and how this halal retailing standard protects halal integrity according to Islamic thought, including fatwas and the local customs of Muslim societies.

Although Malaysia launched the halal retailing standard in 2010, until today no retailer has obtained a halal certificate under this halal standard, whether from the Malaysian halal authority, JAKIM, or in any other country. Hence the question is how to implement halal retailing effectively. This viewpoint discusses the concept of halal retailing, its complexities, and the way forward.

\section{The Concept of Halal Retailing}

The halal retailer is completing an end-to-end halal supply chain, where the halal product is handed over to the consumer upon payment. This handoff is also known as the point of consumer purchase. The goal of halal retailing is 
to guarantee the halal integrity of the halal category at the point of consumer purchase through effective control of the halal category supply chain processes. The following halal retailing formulas can be differentiated:

1. Halal-exclusive retailer. Where an outlet offers halal products only. This halal category is designed to meet the specific needs and halal requirements of the local Muslim community.

2. Halal-segregated retailer. Where an outlet offers both halal and nonhalal products, which are clearly identified and physically segregated on shelves and displays in order to address risks of contamination and perception issues. This halal category is designed to offer, as much as possible, a complete halal category to the mainstream Muslim consumer.

3. Halal-mixed retailer. Where an outlet offers both halal and non-halal products, but where neither are clearly identified or physically segregated. The retailer does not recognise a halal category.

\begin{tabular}{|l|l|l|l|}
\hline & $\begin{array}{l}\text { Halal-Exclusive } \\
\text { Retailer }\end{array}$ & $\begin{array}{l}\text { Halal-Segregated } \\
\text { Retailer }\end{array}$ & $\begin{array}{l}\text { Halal-Mixed } \\
\text { Retailer }\end{array}$ \\
\hline OIC countries & $\begin{array}{l}\text { Supermarkets in Saudi } \\
\text { Arabia, Iran }\end{array}$ & $\begin{array}{l}\text { Supermarkets in } \\
\text { Dubai, Malaysia }\end{array}$ & $\begin{array}{l}\text { Supermarkets in } \\
\text { Morocco, Indonesia, } \\
\text { Turkey, etc }\end{array}$ \\
\hline Examples & $\begin{array}{l}\text { Panda Supermarket } \\
\text { Etka or Refah Chain }\end{array}$ & Carrefour Dubai & Marjane Morocco \\
\hline Non-OIC \\
countries
\end{tabular}

Table 1: Halal Retailing Practices

As can be seen in table 1, all three models can be observed in both OIC and non-OIC countries. What are the implications of the three models for retailers?

The halal-exclusive retailer only carries products that are considered halal according to governing Islamic law and local customs. A dedicated halal retailer in Malaysia, therefore, will not carry alcoholic beverages, non-halal 
meat, products containing animal ingredients that are not halal, cigarettes, and non-food products (such as cosmetics) containing non-halal components. The supply chain to the retailer should be segregated from non-halal items (as defined according to the country's halal standards). In cases of home deliveries, halal logistics should be in place up to the consumer doorstep.

A halal-segregated retailer in OIC countries carries selected non-halal products, but clearly identifies them, while also segregating its processes and physical flows to ensure the halal integrity of the halal category. The retailer should have 'non-halal zones' for alcoholic beverages and other non-halal food products. For refrigerated food items, there are paper (preferred) or plastic bags present to prevent contamination of trolleys and cashier counter conveyor belts. It should also be clearly identified on the shelf if non-food products are non-halal due to non-compliance of certain components. The supply chain to the retailer should segregate halal from non-halal (according to its country's halal policy). In the case of home deliveries, halal logistics services should be offered to ensure that the integrity of halal items is not compromised due to the mixing of halal and non-halal items during delivery to the consumer. For non-OIC countries, a halal-segregated retailer has halal sections: halal shelves and dedicated halal refrigeration displays. For refrigerated food items there are paper (preferred) or plastic bags present to prevent contamination. The supply chain to the retailer should segregate halal from non-halal. Staff at halalsegregated retailers should be well trained to identify the halal from non-halal and avoid mixing at any stage.

The halal-mixed retailer has not designed a halal category for the Muslim consumer. The implication of this formula is that halal integrity is not assured up to the point of consumer purchase, with identification of what is halal being left to the judgement of the consumer based on the product label. Hence, for OIC-countries, this retail formula provides a major corporate reputation risk for both the halal-certified brand owner (supplier) and the retailer.

\section{Complexity in Halal Retailing}

Retail today is complex, with retailers carrying thousands of different stock items, ranging from food (fresh and processed), home care items (e.g. fabric cleaners), personal care items, paper goods (e.g. toilet paper, pampers), kitchen accessories, magazines, and many more. These products are sourced locally, regionally and globally. As margins are relatively low in retailing, there has been a traditional focus on realising cost reductions in logistics through consolidation. Consolidation occurs as much as possible in transport, in sea 
containers, on air cargo pallets (and unit load devices), and in trucks in order to save logistical costs. Consolidation also means putting products together based on temperature requirements, not necessarily based on the halal stat us of a product. Mixing of halal and non-halal can therefore be an unfortunate consequence. Research shows that halal is moving from a product approach to a supply approach, where halal-exclusive and halal-segregated retail formulas will need to comply with halal logistics standards.

Although in the food category halal certification has been quite common, in the case of non-food items this is not the case. To classify a non-food product as non-halal is not as straight forward as identifying pork products and alcoholic beverages. Product composition needs to be assessed in detail, while for animalbased ingredients it is important to know what halal certificate lies behind them (this will address issues such as Halal Certification Body reputation, scope covered by the certification, standards applied, acceptance at destination, etc.). Furthermore, due to the issuing of new fatwas (like the recent fatwa in January 2019 by JAKIM, declaring cigarettes haram), certain products could suddenly be declared haram by the local halal authority.

A critical emerging requirement is the importance of consumer preference and the transparency of a brand owner's halal eco-system-that is, the product ingredients and its processes. The consumer is seldom involved in the elaboration of standards and very rarely consulted on new developments appearing in the market. Also, consumers might not be aware of the scientific procedures behind halal certification, or the specific details of possible halal slaughtering procedures (the use or avoidance of stunning) while also lacking proper knowledge of the differences between madhahib. Halal certification remains by far the most trusted method for consumers to make their purchase decisions, and they largely leave the authorities of their respective countries to deal with the halal stat us of products.

\section{Conclusions and Recommendations}

For a halal retail standard to be successful it should have different classifications of halal retailers for both OIC and non-OIC countries in order to stimulate the availability of halal and minimise hardship for both the consumer and retailer. The halal retailing standard should be prescriptive instead of simply a management standard that leaves the design of halal retailing practices to the retailer, as is currently the case in Malaysia. A halal standard is recommended for halal-exclusive and halal-segregated retailers in both OIC and non-OIC countries. 
As retailers carry thousands of products, decisions on the 'halal-ness' of a product should be supported by the halal authorities. Leaving the decision to individuals undermines trust in a halal retailing system.

Retailers in OIC countries have to understand that they are closing the last mile in the end-to-end halal supply chain. This is a heavy responsibility that should be taken seriously. Halal retailing has consequences for sourcing, operations, and home delivery services. Halal-exclusive and halal-segregated are suitable models. A halal-mixed retail operation is not recommended in OIC countries, as it exposes the corporate reputation of both the halal-certified brand owner (supplier) and retailer.

For non-OIC countries, retailers should ensure availability of halal products. Halal authorities should protect and serve the Muslim community by advising retailers about developing halal categories. This will ensure that halal can go mainstream in non-OIC countries, improving the availability of halal products, which are currently limited to Muslim shops in big cities. Non-OIC countries can therefore practice all three models: halal-exclusive, halal-segregated, and halal-mixed retailer.

\section{Notes}

* Marco Tieman is Professor in the ELM Graduate School at Help University, Malaysia. He conducts research on halal supply chain management and halal risk and reputation management. He obtained his Master's degree in industrial engineering and management science [logistics] with the University of Twente (the Netherlands) in 1997 and his PhD in business management [halal supply chain management] with Universiti Teknologi MARA (Malaysia) in 2013. He is also the CEO of LBB International, a supply chain strategy consultancy and research firm with a specialisation in purchasing, production, and supply chain management. He chaired the development of the international halal logistics standard (IHIAS, 0100:2010) under ICCI-IHI Alliance between 2008 and 2010. He is the corresponding author and can be contacted at: marco.tieman@help. edu.my.

Barbara Ruiz-Bejarano is the Director of International Relations of the Halal Institute of Spain. She is honorary professor at the UNESCO-University of Alicante, with a Chair in "Islam, Culture and Society". She holds a PhD in Islamic Studies and her main research is focused on Muslim communities in non-Islamic societies. She is also the Director of International Relations of the Halal Institute, a Halal Certification Body with headquarters in Spain and Mexico, which has institutional and trade relations with more than 80 countries. Her expertise includes Halal Markets, Products and Service 
Development, Policy Making and Regulatory Affairs, and Cooperation. She has presented lectures at numerous international events and published over 20 papers throughout her career. She can be contacted at: barbara.bejarano@ institutohala.com. 